\title{
The Impact of Downsizing on Survivor Job Satisfaction and Organizational Commitment at a Selected Timber Production Estate, South Africa
}

\author{
Ngirande, Hlanganipai \\ School of Economics and Management, University of Limpopo, South Africa. \\ Email: hlanganipai@yahoo.com \\ Terera, Sharon Ruvimbo \\ Department of Industrial Psychology, University of Fort Hare \\ Private Bag X1314, Alice 5700 \\ sharonruvimboterera@gmail.com \\ Mutodi, Paul \\ Department of Mathematics, Science and Technology in Education, \\ University of Limpopo, South Africa. \\ Email: paul.mutodi@ul.ac.za
}

Doi:10.5901/mjss.2014.v5n6p145

\begin{abstract}
The objectives of this study were to identify the impact of downsizing on employee survivor's job satisfaction and to determine whether a relationship exists between employee job satisfaction and organizational commitment. A questionnaire was administered to 123 randomly selected respondents. The data collected from the survey was analyzed using SPSS software version 20.0 and presented in the form of descriptive statistics and Pearson Product Moment correlations. Results indicated that survivors were much more satisfied and committed to the organization after the downsizing process. Results further indicated that there is relationship between employee job satisfaction and organizational commitment among the survivors of the downsizing process.
\end{abstract}

Keywords: Downsizing, survivors, employee Job satisfaction, employee organizational commitment.

\section{Introduction and Background of the Study}

In today's business environment where most organizations are forced to restructure due to economic meltdowns, downsizing has proven to be a relevant strategy to organizations. The current tendency of organizations to restructure and ultimately to downsize has a major impact on organizations themselves, on their surviving and terminated employees, on the government, and on society as a whole. In fact, it is everyone's problem, and it seems to become a trend from 2000 up to date (Svein, 2002). The late 2000's economic recession climate; particularly December 2007 has persistent and long-lasting consequences on both employees and the organizations themselves. As a result, many organizations that were operating inefficiently have been driven out of business, and most of those that have survived were forced to restructure in order to streamline their operations and achieve operating cost savings that would ensure their continued competitiveness both on the local and global markets.

The main motivation of most downsizing efforts is the desire for an immediate reduction of costs and increased levels of efficiency, productivity, profitability, and competitiveness (Waraich, Bhardwaj \& Yadav, 2011). Over the years, this strategy has generated a great deal of interest among scholars, managers, and the popular press. Some authors suggest that research-based knowledge about downsizing is still relatively underdeveloped (Macky, 2004), while others stress the confusion surrounding downsizing (Gandolfi, 2008). The adoption of strategic downsizing has remained popular (Maurer, 2005), yet significant empirical and anecdotal evidence suggests that the overall consequences are negative (Zyglidopoulos, 2004).

Mirabal and DeYoung (2005) views the term organizational downsizing as a set of activities, undertaken on the part of the management of an organization and designed to improve organizational efficiency, productivity and/or 
competitiveness, and thus an improvement in the organization's overall performance. Downsizing has been a major effort to revitalize organizations. Kroth (2008) argued that, to have the competitive edge and satisfy customers' needs, organizations engage in downsizing as a strategy for shifting the organizational structure from its present to what it should be. The need for change in organizations is due to re-engineering of business processes, increased global competition and the impact of information technology (Burke \& Nelson, 2002).

When downsizing, organizations expect to have quantitative results on the performance of an organization but, because of the sensitive nature of the process and its effects on survivors, organizations will try to implement the process and try to achieve their objectives with minimal negative effects and publicity (Appelbaum \& Donia, 2001). If the downsizing process is not well handled, not only people leaving the organization are affected, but also those who are left behind (survivors). This creates a new psycho-social problem, "survivor syndrome" and additional loss of jobs can occur.

In addition, Morton and Orman (2010) also noted that consequences such as demoralization of the work force; increased worker turnover; decreased cooperation and teamwork; and increased levels of stress, anxiety, absenteeism, and mistakes can follow.

\section{Problem Statement}

Recent studies on the impact of downsizing reveals it to be probably the most pervasive phenomenon in the business world (Blom, 2013). However, in most South African organizations the experience of being a survivor of the downsizing process is little understood; not enough attention is given to address the impact of downsizing upon those who survive job cuts and continue to work in downsized organizations (Chipunza \& Berry, 2010). Many studies have been conducted to explore the effects of downsizing on people leaving the organization while very little information is known about how it affects those who remain behind (survivors). This research, therefore, aimed at investigating the impact of downsizing on survivors' job satisfaction and worker commitment at a timber production estate in South Africa.

\section{Research Objectives}

The research objectives are:

- To investigate the impact of downsizing on survivor job satisfaction;

- To investigate the impact of downsizing on survivor organizational commitment;

- To determine whether a relationship exists between survivor job satisfaction and worker organizational commitment after downsizing and,

- To formulate recommendations for downsizing planners in terms of the remaining employees (survivors).

\section{Research Hypotheses}

- HO: There is no relationship between downsizing and survivor job satisfaction.

- H1: There is a relationship between downsizing and survivor job satisfaction.

- HO: There is no relationship between downsizing and survivor affective, continuance and normative organizational commitment.

- H2: There is a relationship between downsizing and survivor affective, continuance and normative organizational commitment.

- HO: There is no relationship between downsizing and survivor overall organizational commitment.

- H3: There is a relationship between downsizing and survivor overall organizational commitment.

- HO: There is no relationship between survivor job satisfaction and organizational commitment.

- $\quad H 4$ : There is a relationship between survivor job satisfaction and employee organizational commitment.

\section{Review of Literature and Theoretical Orientations}

\subsection{The concepts of downsizing, job satisfaction and organizational commitment}

The concepts of job satisfaction and organisational commitment post downsizing have received serious attention in studies of organisational behaviour. Noer (2001) defined downsizing as a deliberate organisational decision to reduce the workforce in order to increase organisational performance. It is a business strategy based on the notion that "lean means 
better' (Ngirande \& Nel, 2012). The result of the reduction of the workforce is an organisation with a small group of workers known as survivors who are expected to increase the organisation's productivity and competitive advantage (Chipunza, Samuel, 2011). While this approach has been regarded as the best, a serious problem of survivor job satisfaction and commitment arises.

Downsizing survivors might be relieved from the stress of not losing their jobs however survivor syndrome sickness is a common problem among downsizing survivors (Marky, 2004). According to Burke and Nelson (2002), survivor syndrome refers to the various kinds of behaviours and emotions exhibited by employees following organisational downsizing. These behaviours range from low productivity, low morale, increased absenteeism, dissatisfaction, tardiness to turnover. Campbell \& Paper (2006) also add that survivors lose interest in their jobs after a downsizing process. This often results in high job dissatisfaction. According to Mosikidi (2012) job dissatisfaction refers to unpleasable or negative emotional states that result from the appraisal of one's job or job experiences.

In contrast, Appelbaum and Donia, (2001) reports that in some instances, employees whose jobs are spared during downsizing may become more satisfied with their jobs as they may feel that they are of high value to the organisation. This in turn may result in increased organisational commitment, which is the psychological attachment of workers to their organization (Mostert, Rothmann, Mostert \& Nell, 2008).

The manner in which the downsizing process is conducted also has an impact on the organisational commitment of survivors. If survivors perceive the downsizing process to be fair, they respond positively to it by becoming more committed. However, if the survivors of downsizing judge the process to be unfair, employees become less committed to the organisations. Gandolfi (2008) states that downsizing survivors often experience feelings of uncertainty concerning their future in the organisation such that they become less satisfied with their jobs resulting in low organisational commitment and this consequentially leads to high turnover . Therefore, for survivor job satisfaction and organisational commitment to increase, the downsizing process should be conducted in a way which is perceived as fair.

According to Meyer and Allen (1997) there are three different dimensions of commitment, namely affective, continuance, and normative. Affective commitment refers to employees' emotional attachment to, identification with, and involvement in the organization. Employees with a strong degree of affective commitment continue employment with the organization because they want to do so. Continuance commitment refers to an awareness of the costs associated with leaving the organization. Employees whose primary link to the organization is based on continuance commitment remain because they need to do so. Finally, normative commitment reflects a feeling of obligation to continue employment. Employees with a high degree or level of normative commitment feel that they ought to remain with the organization.

To support the above literature, the equity theory has been used to reveal the effects of employee perceptions about the fairness of management decisions related to the downsizing process (Adams, 1965). For example, survivors' reactions are likely to be affected by their level of acceptance; the need to downsize or make employees redundant; the lack of an alternative course of action; the level of prior notification provided by management; the selection criteria used and the decisions made by managers about who should be made redundant; and the way in which the leavers are treated during their period of notice and offered support to find alternative employment (Blau, 2006). If impartiality is observed concerning management decisions and procedures related to these aspects, the incidence of negative attitudes such as reduced job satisfaction and organizational commitment may be reduced (Gandolfi, 2008).

On the other hand, perceptions of unfairness may lead to positive inequity, where particular survivors feel that those made redundant had a greater claim to be retained than themselves; or negative inequity where, for example, survivors identified closely with those made redundant. Positive inequity may lead to survivors experiencing guilt with the result that they work harder, whereas negative inequity may lead to affected survivors reducing their level of job satisfaction and organizational commitment (Brockner, Spreitzer, Mishra, Hochwarter, Pepper \& Weinberg, 2004).

\section{Research Design and Methodology}

A quantitative approach in the form of correlation research design was used as it appeared to be more appropriate in exploring the impact of downsizing on survivor's job satisfaction and organizational commitment in the timber production industry.

\subsection{Population and Sample}

The study population consisted of both male and female lower level and middle level employees who survived from the downsizing process from a selected timber estate in South Africa. The total population size was $180(\mathrm{~N}=180)$. Using the 
RaoSoft sample size calculator, a minimum recommended sample size of 123 respondents was obtained. The respondents were selected using a stratified sampling method.

\subsection{Data collection}

A structured questionnaire was used to collect data for this study. The questionnaire consisted of four sections. The first part consisted of demographic variables followed by downsizing constructs. The last part sought information on survivor job satisfaction and organizational commitment respectively.

Downsizing process was measured using a self-designed 14-item questionnaire with a five -point Likert type rating scale. To measure job satisfaction, Halpern's (1966) 10-item seven-point Likert-type rating scale was used and organizational commitment was measured using Meyer and Allen`s (1997) 18-item Likert scale questionnaire.

\subsection{Reliability of the Questionnaire}

Cronbach's alpha coefficient was used to determine the internal consistence reliability of the questionnaire. As shown in table1below, the Cronbach's alpha reliability coefficient for the downsizing questionnaire was 0.641539 and for the employee job satisfaction was 0.731041 . Organizational commitment questionnaire has a Cronbach's alpha reliability coefficient of 0.668316 and 0.872657 for the whole questionnaire, which is regarded as good.

Table 1: Cronbach's alpha reliability coefficient

\begin{tabular}{|l|c|c|}
\hline \multicolumn{1}{|c|}{ Variable(s) } & \multicolumn{2}{c|}{ Cronbach's Coefficient Alpha } \\
\hline Downsizing questionnaire & Number of items & Alpha \\
Employee Job satisfaction questionnaire & 14 & 0.641539 \\
Organizational Commitment questionnaire & 10 & 0.731041 \\
Overall questionnaire & 18 & 0.668316 \\
\hline
\end{tabular}

\section{Statistical Analysis}

Descriptive statistics in the form of frequencies, percentages, means and standard deviations was used to analyse demographic variables in the study. Pearson Product Moment correlation coefficient was also utilized to measure relationships between the variables (downsizing, survivor job satisfaction and commitment. The level of statistical significance was measured at $p<0.05$.

\section{Results}

\subsection{Sample Description Summary}

Table 2 shows sample description demographic results. The sample consisted of 123 downsizing survivors, (63 males and 60 females). The majority of the respondents were blacks, 79(64\%), whilst the coloureds were 30(24\%) and 14(12\%) were whites. The majority $49(40 \%)$ of the respondents had a certificate level of education whilst a few $8(6 \%)$ had post graduate degrees. However, $71(58 \%)$ of the sample had occupied lower level (staff) positions whilst 52(42\%) were middle management.

The respondents were not equally distributed according to experience with $51(41 \%)$ of the respondents had at least 10-20 years' experience with the organization while 35(28\%) had less than 10 years and $13(11 \%)$ had above 31 years' experience. 
Table 2: Demographic variables

\begin{tabular}{|c|c|c|c|}
\hline \multicolumn{2}{|c|}{ Variable } & Frequency & Percentages (\%) \\
\hline \multirow{2}{*}{ Gender } & Male & 63 & 51 \\
\hline & Female & 60 & 49 \\
\hline \multirow{4}{*}{ Age } & $16-20$ years & 23 & 19 \\
\hline & $21-30$ years & 57 & 46 \\
\hline & $31-40$ years & 26 & 21 \\
\hline & 41 years and above & 17 & 14 \\
\hline \multirow{3}{*}{ Race } & Black & 79 & 64 \\
\hline & White & 14 & 12 \\
\hline & Coloured & 30 & 24 \\
\hline \multirow{5}{*}{ Educational Qualification } & Matric & 32 & 27 \\
\hline & Certificate & 49 & 40 \\
\hline & Diploma & 19 & 15 \\
\hline & Undergraduate degree & 15 & 12 \\
\hline & Post graduate degree & 8 & 6 \\
\hline \multirow{2}{*}{ Position } & Lowe level/Staff & 71 & 58 \\
\hline & Middle level management & 52 & 42 \\
\hline \multirow{4}{*}{ Tenure } & Below10 years & 35 & 28 \\
\hline & $10-20$ years & 51 & 41 \\
\hline & $21-30$ & 24 & 20 \\
\hline & 31 years and above & 13 & 11 \\
\hline
\end{tabular}

\subsection{Measures of Central Tendency}

In order to establish survivor's level of job satisfaction and organizational commitment after downsizing, measures of central tendency and dispersion for the responses of each variable were computed. The results of the analysis are presented in Table 3.

Table 3: Simple Statistics of Downsizing, employee job satisfaction and organizational commitment

\begin{tabular}{|l|ccc|}
\hline \multicolumn{1}{|c}{ Variables } & Number of participants & Mean & Standard Deviation \\
\hline Downsizing & 123 & 3.32276 & 1.3456 \\
Employee job satisfaction & 123 & 2.17168 & 0.5062 \\
Affective commitment & 123 & 2.34146 & 0.62606 \\
Continuance commitment & 123 & 1.99187 & 0.71570 \\
Normative commitment & 123 & 3.31295 & 0.62000 \\
Overall organizational commitment & 123 & 2.90876 & 0.45288 \\
\hline
\end{tabular}

Employee job satisfaction and organizational commitment frequencies for each item after the downsizing process were analysed and are shown in table 3 above. The results showed that the mean $(M)$ level for employee job satisfaction was $(M)=2.17168$, with a standard deviation (SD) of 1.5062 representing moderate job satisfaction. These finding supports a study conducted by Appelbaum and Donia (2001) which found that in some instances, employees whose jobs are spared during downsizing may become more satisfied with their jobs as they may feel that they are of high value to the organisation. The mean survivor attitude score towards downsizing of 3.32276 was the highest, while survivor organizational commitment was $(M)=2.90876$, with a standard deviation $(S D)$ of 0.45288 .

\subsection{Correlation Analysis: (Hypotheses testing)}

Using Pearson correlation coefficient, two-tailed correlation between the independent variable (downsizing) and independent variables (employee job satisfaction and employee organizational commitment) of survivors were computed to determine the strength, direction and statistical significance of the relationships as shown in table 4. 
Table 4: Correlation of survivor components

\begin{tabular}{|c|c|c|c|c|c|c|c|}
\hline \multicolumn{8}{|c|}{ Correlations } \\
\hline & & \multirow[t]{2}{*}{ Downsizing } & \multirow{2}{*}{$\begin{array}{c}\text { Employee Job } \\
\text { satisfaction }\end{array}$} & \multicolumn{3}{|c|}{$\begin{array}{c}\text { Employee Organizational } \\
\text { commitment }\end{array}$} & \multirow{2}{*}{$\begin{array}{c}\text { Overall } \\
\text { Organizational } \\
\text { commitment }\end{array}$} \\
\hline & & & & Affective & Continuance & Normative & \\
\hline \multirow{3}{*}{ Downsizing } & Pearson Correlation & 1 & $.723^{\star *}$ & .374 & $.849^{* *}$ & $.319^{* *}$ & $-.614^{\star \star}$ \\
\hline & Sig. (2-tailed) & & .000 & .247 & .000 & .001 & .000 \\
\hline & $\mathrm{N}$ & 123 & 123 & 123 & 123 & 123 & 123 \\
\hline \multirow{3}{*}{$\begin{array}{l}\text { Employee Job } \\
\text { satisfaction }\end{array}$} & Pearson Correlation & $.723^{* *}$ & 1 & $.738^{* *}$ & $.534^{* *}$ & $.340^{* *}$ & $.961^{* *}$ \\
\hline & Sig. (2-tailed) & .000 & & .000 & .003 & .002 & .000 \\
\hline & \begin{tabular}{|l|l}
$\mathrm{N}$ \\
\end{tabular} & 123 & 123 & 123 & 123 & 123 & 123 \\
\hline \multirow{3}{*}{$\begin{array}{l}\text { Affective } \\
\text { commitment }\end{array}$} & Pearson Correlation & .374 & $.738^{* *}$ & 1 & $.344^{* *}$ & $.493^{* *}$ & $.704^{* *}$ \\
\hline & Sig. (2-tailed) & .247 & .000 & & .061 & .000 & .000 \\
\hline & \begin{tabular}{|l|l}
$\mathrm{N}$ \\
\end{tabular} & 123 & 123 & 123 & 123 & 123 & 123 \\
\hline \multirow{3}{*}{$\begin{array}{l}\text { Continuance } \\
\text { commitment }\end{array}$} & Pearson Correlation & $.849^{* *}$ & $.534^{* *}$ & $.344^{* *}$ & 1 & .265 & .019 \\
\hline & Sig. (2-tailed) & .000 & .003 & .061 & & .104 & .280 \\
\hline & \begin{tabular}{|l|l}
$\mathrm{N}$ \\
\end{tabular} & 123 & 123 & 123 & 123 & 123 & 123 \\
\hline \multirow{3}{*}{$\begin{array}{l}\text { Normative } \\
\text { commitment }\end{array}$} & Pearson Correlation & $.319^{* *}$ & $.340^{* *}$ & $.493^{* *}$ & .265 & 1 & $.330^{* *}$ \\
\hline & Sig. (2-tailed) & .001 & .002 & .000 & .104 & & .002 \\
\hline & $\mathrm{N}$ & 123 & 123 & 123 & 123 & 123 & 123 \\
\hline \multirow{3}{*}{\begin{tabular}{|l|} 
Overall \\
Organizational \\
commitment
\end{tabular}} & Pearson Correlation & $-.614^{* *}$ & $.961^{* *}$ & $.704^{* *}$ & .019 & $.330^{* *}$ & 1 \\
\hline & Sig. (2-tailed) & .000 & .000 & .000 & .280 & .002 & \\
\hline & $\mathrm{N}$ & 123 & 123 & 123 & 123 & 123 & 123 \\
\hline
\end{tabular}

\subsubsection{Hypothesis 1}

The first hypothesis of the study $(\mathrm{H} 0)$ was stated as, "there is no relationship between downsizing and survivor job satisfaction" and the corresponding alternative hypothesis $(\mathrm{H} 1)$, was that, "there is a significant relationship between downsizing and survivor job satisfaction". The results in table 4 show that there is a highly significant relationship between downsizing and employee job satisfaction $(r=0.723, p<0.05)$. Therefore we do reject the null hypothesis. Based on the results, one can argue that downsizing have an impact on employee job satisfaction.

\subsubsection{Hypothesis 2}

The second null hypothesis of the study $(\mathrm{HO})$ was that "there is no relationship between downsizing and survivor affective, continuance and normative organizational commitment" and the corresponding alternative hypothesis $(H 1)$ was that "there is a significant relationship between downsizing and survivor affective, continuance and normative organizational commitment. The correlation between downsizing and employee affective organizational commitment was found to be $(r=, 374 p>0.05)$. This shows that there is no significant relationship between downsizing and employee affective commitment. This means that downsizing process may lead to employee to feel emotionally attached to that particular organization. This leads to the acceptance of the null hypothesis.

As for continuance and normative commitment, a positive significant relationship was found between downsizing and survivor continuance and normative organizational commitment $(r=0.849, p=<0.05$, and $r=0.319, p<0.05$ respectively). Given this, we do not accept the null hence we reject the hypothesis.

\subsubsection{Hypothesis 3}

The third hypothesis was stated as ( $\mathrm{H} 0)$ "there is no relationship between downsizing and survivor overall organizational commitment" and the corresponding alternative hypothesis $(H 1)$ was that "there is a significant relationship between downsizing and survivor overall organizational commitment. There results shows that there is a significant negative relationship between downsizing and survivor organizational commitment $(r=-0.614, p=<0.05)$. Therefore this leads to the rejection of the null hypothesis 


\subsubsection{Hypothesis 4}

The study also hypothesized that $(\mathrm{HO})$ "there is no relationship between job satisfaction and organizational commitment and the corresponding alternative hypothesis stated that $(\mathrm{H} 1)$ "there is a relationship between employee job satisfaction and employee organizational commitment among survivors after the downsizing process. There results show a strong positive significant relationship between employee job satisfaction and employee organizational commitment $(r=0.961$, $p=0.05$ ). This means that as the remaining employees becomes satisfied with their working conditions, they become more committed to the organization. The null hypothesis was there for rejected.

\section{Discussion of Results in Relation to the Hypotheses}

It can be recalled that the purpose of this study was to investigate the impact of downsizing on employee job satisfaction and organizational commitment among survivors at a selected timber production estate in Limpopo Province of South Africa. The results indicate that survivor job satisfaction and commitment were average to satisfactory. The results show that the survivors were satisfied with downsizing process in their organizations. Although survivors perceived the process of downsizing as satisfactory, this probably had an impact on their affective organizational commitment. The findings of this study also support (Chipunza \& Berry, 2010) findings that there is a positive relationship between justice perception and continuance commitment after downsizing.

The results also showed that although the remaining employees (survivors) were satisfied with the downsizing process, they are no longer emotionally attached to the organization but only committed due to the costs associated with leaving the organization. This is also in line with the findings of (Boehman, 2006; \& Kroth, 2008) who argued that downsizing makes survivors develop continuance commitment and cognitive feelings about their organizations and jobs. The combination of how a survivor feels about the organization determines their satisfaction and job involvement. The present findings indicate that the antecedents of such thoughts and feelings, such as ensuring that all procedures and interactions are perceived fair during and after downsizing might have been addressed, but survivors had a lot of other reservations about the whole process.

\section{Conclusions, Recommendations and Limitations of the study}

There seems to be a change in survivor satisfaction and commitment after downsizing. Over and above that, survivors of downsizing experience high overall commitment. The implication of these conclusions for human resources managers is that:

(1)They should have knowledge of the context in which downsizing is taking place. Such knowledge makes them effective in deciding the criteria, processes and procedures to be adopted when downsizing and (2) there should be differential of treatment of employees during and after the downsizing. This might lead to the strengthening of commitment towards the new organizational order.

The managerial challenge, then, is to navigate carefully through the downsizing process and maintain a balance among those who leave (victims) and those who remain (survivors) to ensure positive psychological outcomes for the survivors and positive economic outcomes for the organization.

As part of good research practice, it would have been proper, and more interesting results could have emerged, if the researcher had obtained the levels of survivors' job satisfaction and organizational commitment before the actual downsizing took place and then compare them with levels of these constructs after downsizing.

\section{References}

Adams, J. S. (1965). Inequity in social exchange. In L. Berkowitz (Ed.), Advances in experimental social psychology, 2: $267-299$.

Appelbaum, S. H, \& Donia, M. (2001). The Realistic Downsizing Preview: A Multiple Case Study, Part 1: The Methodology and Results of Data Collection. Journal of Career Development International, 6 (3): 128-150.

Blau, G. (2006). A process model for understanding victim responses to worksite/function closure. Human Resource Management Review, 16: 12-28.

Blom, S. (2013). Identity work' in the context of organisational change: a gestalt perspective. Unpublished PhD dissertation. University of Derby.

Boehman, J. (2006). Affective, Continuance and Normative Commitment among Student Affairs Professionals. [Online] from: http://www.lib.ncsu.edu. (Viewed on 2009/05/06).

Brockner, J., Spreitzer, G., Mishra, A., Hochwarter, W., Pepper, L. \& Weinberg, J. (2004). 'Perceived Control as an Antidote to the 
Negative Effects of Layoffs on Survivors' Organizational Commitment and Job Performance. Administrative Science Quarterly, 49(1): 76-100.

Burke, R, J. \& Nelson, D.L. (2002). Downsizing and Restructuring. Lessons from the Firing Line for Revitalizing Organization, Leadership \& Organization Development Journal, 18: 325-34.

Chipunza, C. \& Berry, D. M. (2010). The relationship among survivor qualities -attitudes, commitment and motivation-after downsizing. African Journal of Business Management, 4 (5): 604-613.

Chipunza, C \& Samuel, M.O. (2011). The Influence of Downsizing Organisational Strategies on Survivor Qualities in an Economically Volatile Environment. Journal of Social Science, 28(2): 87-98.

Gandolfi, F. (2008). Corporate Downsizing Demystified: A Scholarly Analysis of a Business Phenomenon. The ICFAI University Press, Hyderabad, India.

Halpern, G. (1966). "Relative contributions of motivation \& hygiene to overall job satisfaction." Journal of Applied Psychology, 50, 198200.

Kroth, M. S. (2008). The Manager as Motivator. Greenwood Publishing Group.

Marcky, K. (2004). Organizational Downsizing and Redundancies: The New Zealand Workers' Experience. New Zealand Journal of Employment Relations, 29 (1), 63-87.

Maurer, R. (2005). Managing after downsizing. http://eziearticles.com/?Managing after Downsizing\&id=12368. Retrieved August $2007 / 08 / 24$

Meyer, J. P. \& Allen, N. J. (1997). Commitment in the Workplace: Theory, research and application. Thousand Oaks, CA: Sage Publications.

Mirabal, N. \& DeYoung, R. (2005). Downsizing as a Strategic Intervention. Journal of American Academy of Business, 6(1): 39-45.

Morton, C. \& Orman, M.D. (2010). 18 Ways to Survive Your Company's Reorganization, Takeover, Downsizing, or Other Major Change. http://www.stresscure.com

Mosikidi, A. M. (2012). Job satisfaction: correspondence of occupational reinforcers to the individual needs of urban school principals in the Free State. Unpublished thesis: University of Free State.

Mostert, F.F., Rothmann, S. Mostert, K. \& Nell, K. (2008). Outcomes of occupational stress in a higher education institution. Southern African Business Review, 12:3.

Ngirande, $\mathrm{H} \& \mathrm{Nel}, \mathrm{A}$. (2012). The psychological impact of downsizing on employee survivors in the manufacturing industry. African Journal of Business Management, 6(11), 4371-4375.

Noer, D. M. (2001). Healing the wounds: Overcoming the trauma of layoff and revitalizing downsized organisations. USA: Jossey-Bassey Publishers.

Svein, S. (2002). Science and Technology Education Current Challenges and Possible Solutions. Innovations in Science and Technology Education, VIII.

Waraich, S.B., Bhardwaj, G., \& Yadav, N. (2011). An Exploratory Study of Downsized Survivors' Work Behaviour. Management and Labour Studies, 36 (2): 129-142.

Zyglidopoulos, S. C. (2004). The Impact of Downsizing on the Corporate Reputation for Social Performance. Journal of Public Affairs, 4(1): $11-25$ 